\section{Література}

1. О населении губернии по данным всеобщей переписи 1897 г. [Текст] / Херсон, 1905. - 67 с.

2. Скальковский, А. Одесса 84 г. тому назад и теперь [Текст] / А. Скальковский. - Одесса, 1844. - 60 с.

3. Загоровский, А. Славянская колонизация Новороссии [Текст] / А. Загоровский. - К., 1913. - 59 с.

4. Лобачевский, В. Бугское козацтво и военные поселения [Текст] / В. Лобачевский. - К., 1887. - 36 с.

5. Первая всеобшая перепись населення Российской Империи, 1897 г. [Текст] / XLVII. -Херсонская губерния. M.,1904.- 319 c.

6. Могилянский, Н. Природа и население Новороссии как факторы производства [Текст] / Н. Могилянский. - Одесса, 1920. -25 с.

7. Народное образование в Херсонской губернии в 1910 г. [Текст] / Херсон, 1912. - 333 с.

8. Одеська область: Адресна й довідкова книга [Текст] / Одеса, 1934. - $276 \mathrm{c}$.

9. Численность городского и сельского населения на 1 января 1991 г.; Сельские населенные пункты и численность населения в них на 1 января 1990 г. [Текст] / Херсон, 1991.- 31 c.

10. Демченко, В. М. Мовне середовище. Екстралінгвістичний нарис про Південь України [Текст]: монографія / В. М. Демченко. - Херсон: АЙЛАНТ, 2001. $-216 \mathrm{c}$.
11. Демченко, В. М. Органічна та неорганічна українська мова : монографія [Текст] / В. М. Демченко. Херсон: Мрія, 2003. - 188 с.

\section{References}

1. About a population of the province for general census of 1897 (1905). Kherson, 67.

2. Skalkovsky, A. (1844). Odessa 84 years ago and now. Odessa, 60.

3. Zagorovsky, A. (1913). Slavic colonization of New Russia. Kyiv, 59.

4. Lobachevsky, V. (1887). Bug's kozaks and military settlements. Kyiv, 36 .

5. First general Russian Empire Census, 1897 (1904). XLVII. Herson province Moskow, 319.

6. Mohylansky, N. (1920). Nature and population of Novorossia as factors of production. Odessa, 25.

7. Education in Kherson province in 1910 (1912). Kherson, 333.

8. Odessa region: address book (1934). Odessa, 276.

9. The amount of urban and rural population on January 1, 1991. (1991). Rural settlements and population. Kherson, 31.

10. Demchenko, V. M. (2001). Language areal. Extralingvistic novel about South Ukraine: monographia. Kherson, 216.

11. Demchenko, V. M. (2003). Organic and no-organic Ukraine. Kherson, 188.

Рекомендовано до публікащії д-р філол. наук Голобородько К. Ю. Дата надходження рукопису 10.11.2014

Демченко Володимир Миколайович, кандидат філологічних наук, доцент, кафедра державного управління i місцевого самоврядування, Херсонський національний технічний університет, вул. Бериславське шосе, 24, м. Херсон, Україна, 73008

E-mail: d.vovchyk@gmail.com

УДК 811.161.

DOI: $10.15587 / 2313-8416.2014 .31496$

\title{
МЕТОДОЛОГІЯ ДОСЛІДЖЕННЯ СУСПІЛЬНОГО СТАТУСУ РУСЬКОЇ (УКРАЇНСЬКОЇ) МОВИ В ДІАХРОНІЇ (XIV-XVII ст.)
}

\section{() I. Д. Фарioн}

Об'єктом статті є методологія дослідження суспільного статусу руської (української) мови в діахронії (XIV-XVII cm.), в основу якої покладено принцип триєдності ідей, обставин, часу. Еволюиія статусу руської мови проаналізована в контексті ідей доби Відродження, Реформації, Контрреформації та Бароко; у час бездержавного функиіювання та в межах хронологічної періодизації, зумовленої внутрішньомовними та позамовними обставинами

Ключові слова: руська (українська) мова, методологія, діахронія, Відродження, Реформація, Контрреформація, Бароко, мовно-етнічна (національна) свідомість, соціальний тиск, історія ідей

The object of the article is the research methodology of the social status of the Rutenien (Ukrainian) Language in diachrony (XIV-XVII centuries) the basis of which is the principle of trinity of ideas, circumstances and time. The evolution of the Rutenien Language status was analyzed in the context of ideas of Renaissance, Reformation, Counter-Reformation and Baroque; in the period of ungoverned functioning and within the chronological periodization caused by the intralinguistic and extralinguistic circumstances

Keywords: Rutenien (Ukrainian) Language, methodology, diachrony, Renaissance, Reformation, CounterReformation, Baroque, linguistic and ethnic (national) consciousness, social pressure, history of ideas

\section{1. Вступ}

Дослідження суспільного статусу руської (украӥнської) мови в контексті діахронної соціолінгвістики (XIV-XVII ст.) - це перша системна розвідка в українському мовознавстві. Руська мова (саме так іiі називали в аналізовану пору) становить 
собою феномен існування державної мови у бездержавних умовах (принаймні у складі Великого князівства Литовського - далі ВКЛ), у системі ієрархічної багатомовності (латинська церковнослов'янська, польська - руська, церковнослов'янська - руська), у соціолінгвістичній вертикалі своє (руське) - чуже (польське) і горизонталі давнє (церковнослов'янське) - нове (просте руське), в час спалахування і згасання мовно-етнічного (національного) самоусвідомлення i врешті руськомовного вигасання під «соціальним тиском» повної колонізації українців, що, 3 огляду на закон історичного парадоксу, дало можливість вийти на кін історії новій народній мові.

Актуальність обраної теми має подвійне значення: по-перше, це діахронний аналіз не лише мовно-суспільних, але й мовно-філософських, мовнопсихологічних, мовно-етнічних залежностей; подруге, це пізнання політичної природи мови в діахронії як чинника самої влади, що в Україні через iii колоніальний статус тривалий час цією мовою була заступлена. Вивчення траєкторії прогресу та регресу руської, а пізніше простої мови актуальне 3 екзистенційних позицій, позаяк дає промовисту відповідь на запитання про передумови та умови розвитку i занепаду фундаментальної основи існування народу та держави - літературної мови.

\section{2. Постановка проблеми}

Віднайдення методології пізнання мовного минулого - це один зі способів об'єктивної оцінки теперішніх соціолінгвістичних явищ i водночас наукове моделювання їхнього майбутнього. Застосування комплексної методології зумовить зміни стереотипів у трактуванні мови як типового засобу комунікації з переміщенням її сприйняття у площину фундаментальної передумови існування етносу, нації i самостійної держави. Історія мови у всьому комплексі іiі зовнішньої та внутрішньої історії та історії ідей писатиме історію нації та держави.

Руська мова пройшла стрілою різної траєкторії крізь зміну ідейно-філософських епох та світоглядових картин: Відродження, Реформації, Контрреформації та Бароко. Її статус (правове становище, функції, ставлення до мови іiі носіїв та їхня мовна свідомість) і трансформаційний вияв через просту мову - це лінгвосоціальна кардіограма нашого народу в час його злетів i падінь. Досліджуваний «усереднений варіант», яким була руська мова як дитя свого часу, є фокусом вивчення мовної та мовно-етнічної (національної) свідомості в діахронії та однієї 3 форм існування тодішніх елітарних верств суспільства: урядово-шляхетських та духовно-освітніх. Дослідження такої складної проблематики вимагає своєрідної методології, в основу якої кладемо триєдиність ідей, обставин i часу, що і маємо за мету розкрити у цій розвідці.

\section{3. Літературний огляд}

Низка вчених у різні часи принагідно чи 3 погляду різних предметів дослідження порушувала цю тему, проте поза цілісним методологічним контекстом. Виокремлюємо групи провідних учених, що зосереджували свою увагу на характерних сегментах методології, зокрема, хронологічної періодизації мови, що невіддільно пов'язана 3 позамовними суспільно-політичними процесами (Петро Тимошенко, Павло Плющ, Михайло Жовтобрюх, Юрій Шевельов, Олекса Горбач, Василь Німчук, Віталій Передрієнко, Міхаель Мозер та ін.), на функційній та стильовій диференціації руської мови (Віталій Русанівський, Інна Чепіга), на існуванні явищ диглосії (Юрій Шевельов) і білінгвізму (Борис Успенський, Віталій Передрієнко, Інна Чепіга, Василь Німчук), на прикладному застосуванні руської мови у часи ВКЛ та Речі Посполитої (Михайло Грушевський, Іван Франко, Ярослав Ісаєвич, Григорій Півторак, Віктор Мойсієнко, Зігмас Зінкявічюс, Надія Непорожня та ін.), на самій природі руської мови як спільної мови для українців та білорусів чи іiі відокремленому характері (Іван Огієнко, Християн Станг, Лукія Гумецька, Володимир Аниченко, Григорій Півторак, Володимир М'якишев та ін.), на мовознавчій науці того часу (Василь Німчук), на перших діахронних соціолінгвістичних підходах в аналізі функціювання та статусу мови (Іван Могильницький, Яків Головацький, Іван Франко, Михайло Драгоманов, Іван Огієнко, Свген Тимченко, Павло Плющ, Юрій Шевельов, Олекса Горбач, Василь Німчук, Міхаель Мозер, Орест Ткаченко, Ярослав РадевичВинницький та ін.), на теоретичних проблемах діахронної соціолінгвістики (Ян Бодуен де Куртене, Фердинан де Сосюр, Антуан Мейє, Жозеф Вандрієс, Євген Поліванов, Юнус Дешерієв, Володимир Журавльов, Ніна Мєчковська, Василь Бондалєтов, Володимир Беліков, Леонід Крисін та ін.).

\section{4. Основна частина: Триєдиність методології дослідження: ідеї, обставини, час \\ В основі методології дослідження суспільного статусу руської мови лежить: \\ a) пізнання зовнішньої історії мови як «історії ідей», виявлених у зміні ідейно-культурних векторів пізнього Середньовіччя, Відродження, Реформації, Контрреформації та Бароко; \\ б) суспільно-політичні обставини, або «соці-} альний тиск» на мову;

в) поєднання зовнішнього та внутрішньомовного розвитку, виявленого у хронологічній періодизації мови.

Інструментом реалізації цієї методології $\epsilon$ низка методів дослідження, серед яких діахронний соціолінгвістичний метод, психолінгвістичний, статистичний та емпіричний методи, а також метод порівняльно-історичного аналізу та міждисциплінарного дослідження.

Першим складником методології вивчення суспільного статусу руської мови є «історія ідей» як змін у лінгвосоціумі або ж синтезу духовних фокусів часу як змін у культурі $[1,2]$. Ці зміни виявлені через систему цінностей пізнього Середньовіччя, Відродження, Реформації - Контрреформації та Бароко. За Ле Гоффом, «Досліджувати світ уявлень 
якогось суспільства - цуе означає іти в глибину його свідомості і його історичної еволючиї, створеної «за образом Божим» [3]. Розглянемо перший складник пропонованої методології: історію ідей від філософії Середньовіччя до химерного Бароко.

Раннє Середньовіччя (V-XV ст.) - це панування надетнічної священної мови, якою в Русі стала церковнослов'янська, точніше зукраїнізована редакція старослов'янської мови. Така мовна дійсність зумовлена ідеологічно-політичним тлом середньовічної епохи. Основною ідеологією стало християнство, а формою політичного устрою імперія. Надетнічна священна мова не лише сприяла такій ідеологічно-політичній єдності, але й ділила суспільство на «посвячених» і «не посвячених» у цю мову, себто активні носії церковнослов'янської мови зосереджені біля церковних катедр, у монастирях та владичних скрипторіях. Мільйони інших жителів від смерда до великого князя - активно жили своєю рідною мовою [4]. Хоч дух християнства вимагав, аби пастор промовляв до громади і проповідував вчення Ісуса Христа зрозумілою їй мовою, церква i держава як тотожні на цей час інституції чинили цьому запеклий спротив. Елітарна мова неминуче ставала суспільно обмеженою, що формувало протиставлення між мовою священних текстів i народною мовою. Створена опозиція стала засобом вивищення духовної та державної еліти над загалом. Сакральність мови набувала прихованого значення зверхності за принципом сприйняття «незрозумілого», себто чужої священної мови, даної від Бога.

Вінцем середньовічної християнської філософії стала схоластика, в основі якої лежить система християнського світогляду 3 чіткою ієрархією всіх сфер буття на чолі 3 церквою. Запозичена церковнослов'янська мова як «імперська мова богів» [5] очолила цю нову систему цінностей. Народна маса християнізувалась дуже поволі, але ще повільніше демократизувалось християнство, зодягнуте у церковнослов'янську мову. Так народилася лінгвістично-релігійна і лінгвістичнополітична опозиція. Сакральність мови набувала прихованого значення зверхності не тільки через чуже - рідне, а сакральне - світське, культурне і побутове [6]. Відтак із подальшим суспільним розвитком та зміною ідейної парадигми змінювалися i мовні виміри. Середньовічний універсалізм відступав i передусім через «розщеплення вербальномовного рівня ментальності» [1]. Показово й те, що історичні та культурні періоди «наповзають один на одного», а «економіка і культура взагалі не ступають однаковим кроком» [3]. Як стверджують дослідники, кожна країна по-своєму переживала епоху Відродження, яку зазвичай вкладають у XVXVI ст., хоч передвісники «повернення до античності» виникають задовго до того часу. Однак загальновизнаним є те, що це - «епоха філологічна», яка почалася 3 Італії 3 боротьби 3 класичною латиною, і різномовність світу не $є$ його карою чи помстою у контексті біблійної Вавилонської вежі, а правом і виявом багатоликої природи [7]. Через те важливо актуалізувати крізь призму мовної свідомості або ширше - крізь призму «ментальності суб'єкта культури» [1] - так званий ранній, етикофілологічний гуманізм. Наскрізна ознака його - це створення різних білінгвізмів (i мовних, i культурних) на місці середньовічної універсальної монокультурності і монолінгвізму, і передусім через граматики та лексикографічні праці. Яскравий приклад цього перша європейська мовознавча праця (1302-1308 рр.) трактат Данте Аліг’єрі «Про народну красномовність», де вперше розроблено поняття volgare (лаm. vulgare) illustre - «блискуча народна мова». Для порівняння, перша граматика власне української літературної мови XVI-XVII ст. вийшла 1643 року під назвою «Грамматыка словенска4» авторства студента Сорбонни Івана Ужевича [8]. Ці знакові праці об'єднує не лише латиномовний код, а роз'єднує понад трьохсотлітня відстань у часі - їхня знакова спільність у відсутності «теоретичного рівня лінгвістичних рефлексій» [1]. Як Данте Аліг'єрі у XIV ст., так і Іван Ужевич у першій половині XVII ст., попри залучення до тексту живомовного ілюстративного матеріалу, на теоретичному лінгвістичному рівні не сприймали так званої вульгарної латини і класичної латини, а у випадку 3 Іваном Ужевичем - слов'янської мови і руської мови як цілком окремих кодів. Це радше була диглосія, себто сприйняття різновидів чи варіантів тої самої мови [9], 3 характерною відсутністю теоретичних лінгвістичних рефлексій, за яких мовна теорія на рівні мовно-етнічної свідомості не встигала за практикою життя (узусу).

Водночас своєрідна духовно-культурна i суспільно-економічна ситуація в Україні у першій половині XVI ст. виявилася у поширенні етикофілологічного гуманізму через викладання риторики (як «першої опікунки молодих літературних мов» [7]), відтак граматики, а вже 3 другої половини XVI ст. у контексті двох уній, Люблинської (1569р.) і Берестейської (1596 р.), національне Відродження крокує в парі з Реформацією. Польська дослідниця Барбара Отвіновська називає XVI ст. «ренесансом народів $і$ мов» 3 провідною ідеєю інтелектуального та естетичного пристосування народних мов до нової функції і ролі - репрезентації свого народу, що ставало цілком новим баченням i трактуванням мовного розвитку [7].

В останній чверті XVI ст. в українських текстах, а отже, у суспільній свідомості можна спостерігати риси стилю бароко, а XVII ст. взагалі «прийнято ототожнювати 3 епохою Бароко» як мистецтвом Контрреформації [10]. Еклектика стилів, що нестримними хвилями напливали один на одного, найяскравіше зрезонувала у розмаїтті мовної палітри: поєднання протилежного, абсолютна строкатість і мовно-суспільна ієрархія. Як літературні використовують (щоправда, різною мірою) чотири мови: українську, церковнослов'янську (місцевої редакції), польську, латинську [11]. У контексті нових релігійно-політичних умов визріло кризове протистояння між латинською мовою та церковнослов'янською як конфесійно-національний антагонізм між поляками і русинами, католиками і 
православними. Мови маніфестували змагання різних ідеологій (християнської схоластики і гуманізму) і політико-економічних систем (утвердженого феодалізму і новопосталого капіталізму). Мови ставали протилежними світами і передвікниками народження нового світобачення і концептції світу.

Найбільшу роль у цьому відіграла реформація як церковно-релігійна і суспільно-політична течія. Вона стала руйначем сакральних мов і провідником на головну сцену історії мов народних. Таке руйнування народило новий світогляд і відкрило нові народи. Як зауважує теоретик ідеології націоналізму Ернест Гелнер, між Реформацією та націоналізмом існують «дивовижні взаємини». Наголос Реформації на писемності та орієнтація на Святе Письмо, «ї̈ атака на монополістичне духівництво, ї̈ індивідуалізм та зв'язки з мобільним міським населенням, - усе ие надає їи характеру провісника тих соціальних ознак та настроїв, які, згідно з нашою моделлю, породжують епоху націоналізму» [12]. Реформація через народну мову несла нову концепцію світу, яка базувалася на трьох началах. Перше начало - це руйнування ідеї про те, що лише обрана мова, зокрема латинська чи церковнослов'янська, забезпечує привілейований доступ до онтологічної істини - і саме тому, що мова була невіддільною частиною цієї істини. Друге - це руйнування віри в те, що суспільство начебто природним способом підпорядковане верховному центрові - монархові і церкві - себто правління має божественну природу. Третє - реформація роз'єднала нероз'єднувані до того речі: історію і теологію. Друкарство народними мовами як перше диво капіталізму, сферментованого реформацією, сприяло перетворенню цих трьох засад у нову ідеологію [13].

Реформація в Україні мала свої складнощі розвитку: вона опинилася між двох протиборчих $\mathrm{i}$ водночас ворожих до протестантизму сил католицькою Польщею і православною Україною. Це певною мірою пояснює слабке поширення цього нового руху серед усіх прошарків населення. Однак вона таки активізувала православну шляхту, міщанство, козацтво й духівництво, для яких, загрожена католицьким наступом, руська віра набувала ознак національної ідентичності (себто «З $a$ віру $i$ націю руську»). Можна вважати реформацію в Україні ідеологією, що не втілилася у час власного розквіту в Європі, позаяк не мала для цього належної суспільно-духової бази. Відтак наростання української національної революції у середині XVII ст. відкрило Україну до активних впливів бароко. Його розквіт в українській культурі припадає на кінець XVI-XVIII ст., а згасає «разом з притаманною украӥнському бароко літературною мовою: на зміну прийлла мова народна» [14]. Ця доволі симптоматична теза Дмитра Чижевського слушно вкладає бароко у суто мовну площину. Відомо, що це напрям контрастів, різнорідностей, мінливостей і ускладнень; це антагонізм релігійних і світських мотивів на тлі єдності схоластичного середньовіччя 3 ренесансним духовним розкріпаченням людини.
Однак головне лінгвістичне досягнення XVI ст. полягає у формуванні книжної української мови (себто простої мови), що постала на основі державної руської мови ВКЛ, насиченої церковнослов'янськими та народномовними елементами, яка до середини XVI ст. потіснила церковнослов'янську мову навіть у жанрі релігійної літератури [15].

Поряд із цим надзвичайно високим був авторитет церковнослов'янської мови, що зумовлено наступом католицизму 3 його головною формою латинською мовою. Отож строкате, суперечливе, химерне бароко розігрувалось на не менш барвистому і строкатому мовному тлі: як літературні мови вживають церковнослов'янську (словенську чи словенороську), книжну українську (руська мова, проста мова), польську, меншою мірою грецьку i народну українську, яка проривалася у літературні сфери через побутове віршування, інтермедії, козацькі думи та як компонент книжної української. Крім того, мова варіювала (у цьому і мінливість бароко) залежно від жанру твору i навіть його окремої частини, сягаючи «високого стилю» через церковнослов'янську і спадаючи до «низького», через простонародну.

Світове історичне тло того періоду - це перехід до так званого Нового часу, що став розвитком i утвердженням нових економічних відносин (перша буржуазна революція в Нідерландах 1566 р. та в Англії 1640 р.). Ці змагання розгорталися на очевидному релігійному тлі: боротьбі між католиками - основою папського престолу і феодального ладу, та протестантами - ідеологічними й економічними передвісниками капіталізму з базовою вимогою передання папської влади місцевим правителям. Крім релігійного протистояння, розгортався антагонізм між централістичними прагненнями монархів і децентралістичними бажаннями провінцій. Це створювало підгрунтя для основної ідеологічної події того столітнього порубіжжя: усвідомлення належності до етнічної спільноти, що протиставляла звичаї, історичну пам'ять, мову та політичні структури одних народів іншим. I хоч у XVI-XVII ст. поняття нації часто не збігалося 3 політичними кордонами незалежних держав, але, попри те, їхнє існування проявлялося на різних рівнях культури та місцевої автономії [16]. Україна, опинившись у Речі Посполитій, у цьому сенсі стала надважливим компонентом складного польсько-литовського утворення. Люблинська унія, вирішивши проблеми шляхетського стану, одночасно перетворила українців і білорусів на третьосортне населення, незважаючи на те, що воно складало 9/10 Литовської держави, а українські землі у складі Польщі становили близько 1/3 iї території. Натомість Україна на ту добу стала згустком усіх проблематичних аспектів структури суспільства та національної свідомості краю: у XVII ст. «військовий цุех» козаків поступово ставав носієм не лише національної свідомості, але й конфесійної належності; церковна ієрархія та гетьманат жили у стосунках злагоди або напруження 3 панівною 
державною владою, політична лояльність до наднаціональної держави призводила до драматичних страждань, які перетворили Україну «на дуже особливий випадок нації без держави» [16].

Другим складником методології вивчення суспільного статусу руської мови крізь призму мовної свідомості $є$ історико-політичні обставини. На думку Жозефа Вандрієса, «розвиток мов - це лише один із видів розвитку суспільства», натомість суспільство - «ие сукупність суспільної свідомості» [17]. Розпад Київської держави під впливом зовнішніх та внутрішніх чинників і відокремлення феодальних князівств у другій половині XII ст., зруйнування Києва 1240 року і перетікання державного центру у XIII ст. до Галицько-Волинської Руси, що проіснувала до 1341 року, а відтак перебування України (Наддніпрянщина, Волинь, Поділля) у складі ВКЛ (за винятком Галичини, Буковини та Закарпаття), а з 1569 року у складі Речі Посполитої, - промовляють про існування руської мови у тілах чужих держав. Це і стало основним історико-політичним тлом розгортання непростих соціолінгвістичних процесів. Міхаель Мозер половину XIII ст. називає закінченням «першого золотого віку української мови та письменства» [18]. Додав мовних змін на зламі XIV-XV ст. і так званий II-ий церковнослов'янський вплив, що лише поглибив прірву між церковнослов'янською та руською мовами [18]. Переміщення центру культурного життя 3 Києва на захід, у галицьковолинські землі, спричинило зміну діалектної основи актової мови: нею стали північно-західні говірки поліські за своєю структурою. Саме на західному українському Поліссі почали працювати й перші українські канцелярії [19]. Нові історичні процеси максимально послабили зв'язки 3 північно-східними землями колись імперської Руси і натомість поглибили їх із білоруськими землями, що врештірешт вилилося у спільну західноруську, чи украӥнсько-білоруську мову (тобто руську за тодішньою термінологією).

На рубіконовості XIV ст. зауважив історик мови Іван Огієнко: «...з XIV-го cm. розвій украӥнської літературної мови пішов зовсім іншою дорогою. До иьього часу всі східнослов'янські племена були міцно пов'язані спільністю віри (одна Київська митрополія), культури й літературної мови, тепер же, коли Украӥною заволоділа Литва, то вона, Україна, зовсім одірвалася від північних племен і далі творила свою культуру, а в тому й літературну мову, в зовсім інших обставинах $i$ самостійно, $з$ помітно більшим західним впливом» [20]. Починаючи 3 XIV ст., маємо корпус грамот із Польщі та Литви, писаних канцелярійною мовою 3 якнайменшим домішком церковнослов'янізмів і водночас мішаниною білоруських та українських діалектних рис, що виправдує для тієї ранньосередньоукраїнської доби вживання терміна руський з охопленням української та білоруської мови [18]. Отож XIV ст. - це та межа, де територіально-мовний простір членується не лише лінгвально, але й адміністративно: на українських землях однозначно виділяються два діалектні маси- ви - галицький i волинський, що пов'язаний iз північноукраїнським наріччям; Галич i Волинь опиняються по різні боки кордонів у складі інших держав.

Входження Руси до складу різних держав мало свої особливості щодо абсолютної чи часткової втрати незалежності і, відповідно, траєкторії статусу руської мови. У складі ВКЛ руська мова як у жодній іншій державі мала статус державної, а Русь зберігала до 1470 року свою державну незалежність у вигляді місцевих українських династій, аж поки великий князь Вітовт не заступив українських князів своїми намісниками. Остаточну незалежність Україна втратила наприкінці XV ст. Власне, період $\mathrm{XIV}-\mathrm{XV}$ ст. - це виникнення і функціювання під впливом народного мовлення i на основі давньоруської літературної мови так званої українсько-білоруської мови, чи південно-західноруської (на ту пору руськоі), «яка залежно від живомовного оточення виявляється в двох варіантах - південному, украӥнському, й північному, білоруському» [21].

Очевидне обмеження статусу руської мови починається від Люблинської унії 1569 року, що завершується повним поглиненням України Річчю Посполитою і рішенням Варшавського сейму 1696 року про обов'язковість писаря писати попольському, а не по-руському. Серед ієрархічно провідних суспільних станів того часу, крім шляхти та міщанства, на історичну арену виходить мілітарний стан - козацтво, що не переставав бути фокусом політичної боротьби від 1490 до 1764 року. Тому мовний характер козацько-гетьманських канцелярій - це грунтовне відображення мовного статусу та мовної свідомості провідної войовничої еліти. Характерно, що остаточна ліквідація автономії Гетьманщини призвела до повного змосковлення руської мови, відтак іiі змертвіння і занепаду [5]. Проте торжество «другого золотого віку українського письменства» [18] на межі XVI-XVII ст. завдячує фактам церковної історії: полеміка навколо церковної унії 1596 року народила не просто низку знакових руськомовних творів, а заклала основи для створення етнічної спільності всупереч усталеній конфесійній спільноті, що стало революційним кроком у національному самоусвідомленні.

Третім складником методології вивчення суспільного статусу руської мови $є$ синтез внутрішньомовного і зовнішнього розвитку мови, що виявлений у іiі хронологічній періодизації. Періодизація «належить до найзлободенніших $і$ найскладніших (хоч простою вона ніколи не була) проблем нашої лінгвістики, бо в ній переплітаються суто мовознавчі проблеми з суспільними» [22]. Не випадково цитований автор наголошує, що у питаннях глотогенези «досі мало враховуються суспільні фактори, постулати сочіолінгвістики» [22]. У радянські часи наскрізним було поняття давньоруської народності часів Руси, що $з$ XIV-XV ст. трансформується у три східнослов'янські народності - українську, білоруську, російську і, відповідно, у їхні мови [23]. Сьогодні ж доктрина «про 
давньоруську народність» легко розхитується 3 допомогою не лише базових тепер понять етнос, народ, нація, а передусім 3 допомогою термінів, що, за Освальдом Шпенглером, є «ідеями епохи» [2]: ментальність, етнічна свідомість, національна самосвідомість, мовна свідомість тощо. 3 огляду на радянський «дуx часу», академічний Курс історії української літературної мови подає літературну мову Руси як вихідну основу трьох східнослов'янських мов, а період XIV-XVIII ст. названо «літературною мовою украӥнської народності» 3 двома підперіодами, межею для яких $є$ так зване «возз'єднання» 3 Московським царством [14, 23]. Академічна «Історія української мови. Фонетика», базуючись на «трьох східнослов'янських народностях», зауважує на головних особливостях «давньоукраїнської мови XIV cm.» [24]. На тій самій методологічній основі, але деталізованіше запропоновано періодизацію у навчальному підручникові Павла Плюща [25]. Вишівський підручник 3 історичної граматики трактував цей період як «давня українська мова (XIV-XVIII cm.)» на противагу до давньоруської мови XI-XIII ст. [26]. Повоєнні наукові академічні кола Києва та Львова культивували свою періодизацію з відповідною термінологією:

1. Спільнослов'янський, або давньосхіднослов’янський період (VII-X ст.).

2. Давньоруський період (XI-XIII ст.).

3. Староукраїнський період (XIV-XVIII ст.).

4. Новоукраїнський період (XIX-XX ст.) [27].

Новий методологічний підхід пропонує Олекса Горбач. Він визначає староукраӥнську добу X першої пол. XIV ст., середньоукраӥнську добу другої пол. XIV - поч. XIX ст. і новоукраӥнську добу від кін. XVIII ст. - XX ст. [28]. В основі періодизування вісім засад, які загалом вкладаються в містку авторову тезу: якщо історія літератури - це історія стилів, то історія мови - це «історія ізоглос», тобто географія однотипних мовних явищ [28]. Пропоновані засади - це синтез законів внутрішнього розвитку мови 3 зовнішніми культурно-політичними процесами; відношення літературної мови до іiі діалектів; ㄲï функційно-стилістичне розшарування тощо [28]. Характерно, що початок середньоукраїнської доби вчений хронологізує умовно: 1350/1400 pр., долучаючи пів століття до кінця староукраїнської доби: 1240-1350рр., гадаємо, що без особливої на те мотивації.

Юрій Шевельов також виокремлює середньоукраӥнський період, що містить: ранньосередньоукраїнський - від початку XV до середини XVI ст. і середньоукраїнський - від середини XVI ст. до перших років XVIII ст., пізньосередньо-український решта XVIII ст. Натомість XIV ст. долучено до староукраӥнського періоду, з огляду на «дуже умовну» історичну дату: 1387 рік - час початку довготривалого панування Польщі над Галичиною, а Луцьк на ту пору потрапляє під владу литовського правителя князя Вітовта, хоч у процесі дослідження останнє десятиліття $\mathrm{XIV}$ ст. учений долучає вже до ранньосередньоукраїнського періоду [29].

Василь Німчук, системно проаналізувавши основні схеми періодизації - від канонізованої радянською наукою Олексія Шахматова [27] до напрацювань українських мовознавців половини ХХ ст. Степана Смаль-Стоцького, Євгена Тимченка, Костя Німчинова, Агатангела Кримського, Леоніда Булаховського, Петра Тимошенка, Олекси Горбача, Юрія Шевельова та ін., - запропонував власну версію періодизації як напряму дослідження генези та історії української мови. Характерно, що лише цей автор, виписуючи свою схему історії мови, оперує поняттями етнічна мова, мовна свідомість, що моделює етнічну свідомість і навпаки [22], наголошує на понятті регіональної етнічної свідомості як основі творення нових народів [22], зв'язку між етнічною свідомістю та автоідентифікацією чи алоідентифікацією, виок-ремлює «свідомість генетичної спорідненості», що об'єднує носіїв різних діалектних систем в етнос. Врешті наголошує на тріумвіраті, що сприяє «виробленню єдиної етнічної свідомості»: одна (спільна) літературно-писемна мова, одна (спільна) релігія з ії священною мовою, одна держава [22]. Себто до умов періодизації внесено не лише самоочевидні внутрішньоструктурні характеристики всіх рівнів (фонології, граматики, лексики, словотвору, фразеології, акцентуації), а важливі «соціальні параметри»: мовна самосвідомість носіїв мови, наявність чи відсутність єдиної писемності, соціального престижу діалектів, традиції тощо [22]. Отож у пропонованій періодизації Василя Німчука давньоруськоукраӥнська мова охоплює період XI-XIII ст., тоді як період XIV/XV - кінець XVII ст. названо часом середньоукраӥнської мови, пізня середньоукраӥнська мова - це друга половина XVI - кінець XVII ст., а новоукраїнську мову датовано від кінця XVII ст. [27].

Попри всі хронологічні розрізи, найбільшим досягнення середньоукраїнського періоду була формалізація руської мови у певний час у свідомості мовців як простої, доступної читачеві й закоріненої в традицію і водночас опозиційної до польської та церковнослов'янської мов. Вона стала тією ментальною кладкою між мовним середньовіччям і передмодерним часом, яку згодом природно знесла бурхлива течія народної мови наприкінці XVIII ст. (доба Романтизму) - і руська мова відійшла в історію. Поряд із тим, напрацьовуючи періодизацію історії мови, варто брати до уваги слова відомого теоретика мови Яна Бодуена де Куртене про те, що «періоди розвитку мови не змінювалися почергово, як один караульний іншим, але кожен період створював щзось нове, щзо при непоміченому переході $у$ наступний містить підоснову для подальшого розвитку» [30].

\section{5. Апробація результатів дослідження}

Основні результати дослідження викладено на I Міжнародній конференції «Украӥнська соиіолінгвістика поч. XXI ст.: напрями, здобутки, перспективи» (Київ, 2010 р.), на V, VI, VIII Bceукраїнських соціолінгвістичних семінарах (Львів, 2008, 2009, 2011 рр.), на Тимченківських наукових читаннях «Пам'ятки української мови: текст $i$ 
контекст» (Львів, 1013 р.), на Наукових читаннях, присвячених пам'яті Інни Петрівни Чепіги (Київ, 2009 р.), на Міжнародній науковій конференції «нновачійні прочеси в лексищі та граматиці української мови» (Луцьк, 2013 р.), на VI Міжнародному симпозіумі україністів Середньої та Східної Свропи (Оломоуц 2014 р.), на XIII Міжнародній науковій конференції «Проблеми украӥнської термінологї СловоСвіт» (Львів, 2014).

\section{6. Висновки}

Методологія дослідження суспільного статусу руської (української) мови в діахронії крізь призму триєдності ідей, обставин і часу вможливлює виявити і простежити еволюцію змін мовної та етнічнонаціональної свідомості. В основі цього лежав подвійний стандарт самоідентифікації за етнічним походженням і державною належністю, висловлений головною ідеологемою того часу gente Ruthenus, natione Polonus - «народу украӥнського, держави Польської). Це породжувало неминучі протилежні моделі мовно-суспільної поведінки: тяжіння до чужого та ідентифікацію свого, названого прирожоним язиком. Основним генератором ідей та їхнім монополістом у пору Середньовіччя, Відродження, Реформації та Контрреформації була церква як інституція та іiі духовно-освітні середовища. Ставлення руської церкви до руської (простої) мови було іспитом на віднайдення та утвердження руськомовної ідентичності i спроможності на власну реформу. Живий струмінь Відродження та Реформації захитав консервативність церковнослов'янського простору i проста мова, продираючись крізь світоглядові упередження та ортодоксальність, увійшла до сакральних текстів 3 винятково прагматичною мотивацією: аби зрозумів читач, 3 огляду на закритість для нього церковнослов'янської мови. Проте цього було замало, щоб церква стала провідником у розвиткові мовноетнічної (національної) свідомості та кристалізації руської ідентичності.

Отож еволюція статусу руської мови впродовж XIV-XVII ст. крізь призму пропонованої методології це плюсово-мінусова синусоїда в координатах ідейнофілософської та суспільно-політичної доби. Її послідовне виривання 3 лещат середньовічної мовної ієрархії - це виростання мовної, мовно-етнічної та національної свідомості, що не закінчилося зі смертю так званої простої руської мови, а навпаки, трансформувалося у народномовну стихію українську народну мову, - благословенну вже добою Романтизму.

\section{Литература}

1. Собуцький, М. А. Мовна і культурна свідомість західноєвропейських «ренесансів» і динаміка альтернативних ментальностей [Текст] / М. А. Собуцький // Філософська і соціологічна думка. - 1991. - № 4. - С. 101-112.

2. Шпенглер, Освальд. Закат Европы: Очерки морфологии мировой истории. Т. 1. Образ и действительность [Текст] / Ю. П. Комментариев, Бубенков, А. П. Дубнов; пер. с нем. Н. Ф. Гарелин, О. Шпенглер. Минск: ООО «Попури», 1998. - 688 с.

3. Ле Гофф, Жак Середньовічна уява. Есеї [Текст] / Жак Ле Гофф; пер. 3 франц. Яреми Кравця -
Львів: Літопис, 2007. - 350 с.

4. Алексеев, А. А. Почему в Древней Руси не было диглосси [Текст] / А. А. Алексеев. - Литературный язык Древней Руси. - Ленинград: изд-во Ленинградского университета, 1986. - С. 3-11.

5. Ткаченко, О. Українська мова і мовне життя світу [Текст] / О. Ткаченко. - К.: Спалах, 2004. - 272 с.

6. Успенский, Б. А. Языковая ситуация Киевской Руси и ее значение для истории русского литературного язика [Текст] / Б. А. Успенский. - Москва: Изд-во Московского университета, 1983. - 143 с.

7. Otwinowska, B. Język - naród - kultura. Antecedencje i motywy renesansowej myśli o języku [Text] / B. Otwinowska. - Wrocław, 1974. - 288 p.

8. Білодід, І. К. Граматика слов'янська І. Ужевича [Текст] / підготували до друку І. К. Білодід, Є. М. Кудрицький. - Київ: Вид-во Наук. думка, 1970. - 111 с.

9. Туманян, Э. Г. Язык как система социолингвистических систем. [Текст] / Э. Г. Туманян. Москва: Наука, 1985. - 246 с.

10. Ісіченко, I. А. Історія української літератури: епоха Бароко (XVII-XVIII ст.) [Текст] : навч. пос. / Ігор Iсіченко. - Львів - Київ - Харків: Святогорець, 2011. - 568 с.

11. Німчук, В. Конфесійне питання і українська мова кінця XVI - початку XVII століть [Текст] / В. Німчук // Берестейська унія і українська культура XVII століття. Львів: Інститут історії Церкви Львівської Богословської Академії, 1996. - С. 1-48.

12. Гелнер, Е. Нації та націоналізм [Текст] / Е. Гелнер // Націоналізм: Антологія; упоряд. О. Проценко, В. Лісовий. - К.: Смолоскип, 2000. - С. 292-310.

13. Андерсон, Б. Уявлені спільноти. Міркування щодо походження й поширення націоналізму [Текст] / А. Бенедикт. - К.: Критика, 2001. - 271 с.

14. Чижевський, Д. Історія української літератури (від початків до доби реалізму) [Текст] / Д. Чижевський. Тернопіль: МПП «Презент», за участю ТОВ Феміна, 1994. $-480 \mathrm{c}$.

15. Чепіга, I. Концепція літературної мови староукраїнських книжників XVI - першої половини XVII ст. [Текст] / I. Чепіга // Жанри і стилі в історії української літературної мови. - К.: Наук. думка, 1989. - С. 79-93.

16. Беркофф, Дж. Б. Ренесансні історіографічні міфи в Україні [Текст] : зб. наук. пр. / Д. Б. Беркофф // Україна XVII століття: суспільство, філософія, культура. - К.: Критика, 2005. - с. 421-435.

17. Вандриес, Ж. Язык (лингвистическое введение в историю) [Текст] / Ж. Вандриес; пер. с фр., изд. 3-е, стереотипное - М.: Едиториал УРСС, 2004. - 408 с.

18. Мозер, М. Огляд історії української мови середньої доби [Текст] / М. Мозер; за заг. ред. С. Вакуленка // Причинки до історії української мови. - Харків: Харк. істор.-філолог. тов-во, 2008. - С. 40-54.

19. Півторак, Г. П. Державна мова у Великому князівстві Литовському і проблема розмежування українських та білоруських писемних пам'яток [Текст] / Г. П. Півторак // Мовознавство. - 2005. - № 3-4. - С. 80-84.

20. Огієнко, І. Історія української літературної мови [Текст] / І. Огієнко. - К.: Либідь, 1995. - 293 с.

21. Німчук, В. В. Походження й розвиток мови української народності [Текст] / В. В. Німчук. - Українська народність. Нариси соціально-економічної і етнополітичної історії. - Київ: Наук. думка, 1990. - С. 191-234.

22. Німчук, В. В. Періодизація як напрямок дослідження генези та історії української мови [Текст] / В. В. Німчук // Мовознавство. - 1997. - № 6. - С. 3-14.

23. Курс історії української літературної мови (дожовтневий період). Т. І. [Текст] / за ред. І. К. Білодіда. Вид-во АН УРСР, 1958. - 595 с. 
24. Жовтобрюх, М. А. Історія української мови. Фонетика [Текст] / М. А.Жовтобрюх, В. М. Русанівський, В. Г. Скляренко. - К., 1979. - 372 с.

25. Плющ, П. П. Історія української літературної мови. Підручник [Текст] / П. П. Плющ. - К.: Вища школа, 1971. -423 c.

26. Безпалько, О. П. Історична граматика української мови [Текст] : підручник / О. П. Безпалько та ін.; 2-ге вид. випр. - К.: Радянська школа, 1962. - 510 с.

27. Німчук, В. В. Періодизація як напрямок дослідження генези та історії української мови [Текст] / В. В. Німчук // Мовознавство. - 1998. - № 1. - С. 3-12.

28. Горбач, О. Генеза української мови та іiі становище серед інших слов'янських [Текст] / О. Горбач // Зібрані статті. III. Історія української мови. - Мюнхен: Український вільний університет, 1993. - С. 5(4)-17(30).

29. Шевельов, Ю. Історична фонологія української мови [Текст] / Ю. Шевельов; пер. 3 англ. С. Вакуленко, А. Даниленко. - Харків: Акта, 2002. - 1054 с.

30. Бодуэн дэ Куртэнэ, И. А. Вступительная лекция по кафедре сравнительной грамматики индоевропейских языков, читанная 17/29 декабря 1870 г. В С.-Петербургском университете. Т. I [Текст] / И. А. Бодуэн дэ Куртэнэ. М.: Изд-во АН СССР, 1963. - С. 47-77.

\section{References}

1. Sobutskyi, M. A. (1991) Lingual and Cultural Consciousness of the West-European 'Renaissances' and Alternative Mentalities Dynamics. In: Philosophic and Sociological Thought, 101-112.

2. Spengler, O.; Garelin N. F. (Ed.) (1998). The Decline of the West: Outlines of a Morphology of World History. V. 1. Form and Actuality. Minsk: Popuri LLC, 688.

3. Le Goff, J. (2007). The Medieval Imagination. Essays. Translated from French by Iarema Kravets. Lviv: Litopys, 350.

4. Alekseev, A. A. (1986). Why Ancient Rus Had No Diglossy. In: Ancient Rus Literary Language. Leningrad: Publishing House of the Leningrad University, 3-11.

5. Tkachenko, O. (2004). Ukrainian Language and Lingual Life of the World. Kiev: Spalakh, 272.

6. Uspenskiy, B. A. (1983). Lingual Situation of Kievan Rus and Its Significance in the History of Russian Literary Language. Moscow: Publishing House of the Moscow University, 143.

7. Otwinowska, Barbara. (1974). Język - naród kultura. Antecedencje i motywy renesansowej myśli o języku. Wrocław, 288.

8. 'Slavonic Grammar' by Ivan Uzhevych (1970). Kyiv: Naukova Dumka, 111.

9. Tumanian, E. G. (1985). Language as a System of Sociolinguistic Systems. Moscow: Nauka, 246.

10. Isichenko, I. A. (2011). History of Ukrainian Literature: the Epoch of Baroque (XVII-XVIII c.). Textbook for Higher Education Students. Lviv - Kyiv - Kharkiv: Sviatohorets, 568.

11. Nimchuk, V. (1996). Confessional Issue and Ukrainian Language of the End of XVI - Beginning of XVII centuries. In: Union of Brest and Ukrainian Culture of XVII century. Lviv: Institute of Church History of Lviv Theological Academy, 1-48.

12. Gellner, E. (2000). Nations and Nationalism. In: Nationalism: Anthology. Kiev: Smoloskyp, 292-310.
13. Anderson, B. (2001). Imagined Communities: Reflections on the Origin and Spread of Nationalism. Kiev: Krytyka, 271.

14. Chyzhevskyi, D. (1994). History of Ukrainian Literature from Its Beginnings to the Period of Realism. Ternopil: Present Small Private Enterprise, with Femina LLC, 480.

15. Chepiha, I. (1989). Concept of Literary Language of Old Ukrainian Scribes of the XVI - First Half of XVII c. In: Genres and Styles in the History of Ukrainian Literary Language. K.: Naukova Dumka, 79-93.

16. Bercoff, G. B.; Dovha, L., Iakovenko N. (Eds.) (2005). Renaissance Historiography Myths in Ukraine. In: Ukraine of XVII Century: Society, Philosophy, Culture: Collection of Scientific Works in Tribute to the Memory of Professor Valeriia Mykhailivna Nichyk. Kiev: Krytyka, 421-435.

17. Vendryes, J. (2004). Language: A Linguistic Introduction to History. Translation from French, $3^{\text {rd }}$ edition, stereotyped. Moscow: Editorial URSS, 408.

18. Moser, M. (2008). Overview of the Ukrainian Language History of Middle Age. In: Additions to the Ukrainian Language History; General edition by Serhiy Vakulenko. Kharkiv: Kharkiv Historical-Philological Society, 40-54.

19. Pivtorak, H. P. (2005). State Language in Grand Duchy of Lithuania and Problem of Separation of Ukrainian and Belorusian Written Monuments. In: Movoznavstvo, 3-4, 80-84.

20. Ohienko, I. (1995). History of Ukrainian Literary Language. Kiev: Lybid, 293.

21. Nimchuk, V. V. (1990). Origin and Development of the Language of Ukrainian Ethnic Group. In: Ukrainian Ethnic Group. Outlines of Social-Economic and Ethnopolitical History. Kiev: Naukova Dumka, 191-234.

22. Nimchuk, V. V. (1997). Periodization as Ukrainian Language Genesis and History Research Direction. In: Movoznavstvo. 6, 3-14.

23. Bilodid, I. K. (Ed.) (1958). Course of Ukrainian Literary Language History (pre-October period). Publishing House of USSR Academy of Sciences, I, 595.

24. Zhovtobriukh, M. A., Rusanivskyi, V. M., Skliarenko, V. H. (1979). History of Ukrainian Language. Phonetics. Kiev, 372.

25. Pliushch, P. P. (1971). History of Ukrainian Literary Language. Textbook. Kiev: Vyshcha Shkola, 423.

26. Historical Grammar of Ukrainian Language: Textbook / O. P. Bezpalko and others (1962). $2^{\text {nd }}$ edition, revised. Kiev: Radianska Shkola, 510.

27. Nimchuk, V. V. (1998). Periodization as Ukrainian Language Genesis and History Research Direction. In: Movoznavstvo, 1, 3-12.

28. Horbach, O. (1993). Genesis of Ukrainian Language and Its Position Among Other Slavonic Languages. In: Collected Articles. III. History of Ukrainian Language. Munich: Ukrainian Free University, 5(4)-17(30).

29. Sheveliov, I.; Vakulenko, S., Danylenko A. (Eds.) (2002). A Historical Phonology of the Ukrainian Language. Kharkiv: Akta, 1054.

30. Baudouin de Courtenay, I. A. (1963). Introductory Lecture on the Department of Indo-European Languages Comparative Grammar, read on December 17/29, 1870 in Saint-Petersburg University In: Selected Works on General Linguistics. Moscow: Publishing House of USSR Academy of Sciences, I, 47-77.

Фаріон Ірина Дмитрівна, доцент, кандидат філологічних наук, Народний депутат України VII скликання, Перший заступник голови комітету з питань освіти та науки, Верховна Рада України, вул. Грушевського, 5, м. Київ, Україна, 01001 